\title{
Discourse Changes in Brazilian Teacher Education
}

\author{
Alexandre Costa ${ }^{1}$, Izabel Magalhães ${ }^{2, *}$ \\ ${ }^{1}$ University of Goiás, Goiânia (Goiás), 74673-480, Brazil \\ ${ }^{2}$ University of Brasília, Federal University of Ceará and CNPq, Fortaleza (Ceará), Brazil \\ *Corresponding author: mizabel@uol.com.br
}

Received March 15, 2015; Revised April 03, 2015; Accepted April 08, 2015

\begin{abstract}
Over the last two decades, Brazil has promoted almost one hundred percent access of the population in school age to mainstream schools. At the first stage, the epistemological basis of this change was the relation among the subjects across the curriculum. However, it was imposed through top-down processes of continuing teacher education, disconnected of the real conditions of schools, which resulted in demotivating teachers. In fact, it was a process of transcontextual techniques used as strategies in a variety of contexts, characterized mainly by disembedding practices. It was associated with salary devaluation of basic education teachers, and cut down the impact of this new curriculum; it also caused teachers to be confused and hopeless. But nowadays the adoption of the full-day in school model has allowed for changes in school activities. The need to stay at school during the whole day not only developed teachers' awareness about their real working conditions, but also caused education policies to adapt to local practices. We carried out observation of this process in 10 schools of the state of Goiás, in the Midwest region of Brazil. In addition to the change that we have mentioned, we can note that these schools are observed by an educational institute of the third sector in teacher education. Our research can be characterized as ethnographic, with field notes of our class observation, long interviews with teachers, and archive data; it is also collaborative. Our analysis indicates that teachers are exhausted by their daily work demands. However, they have become aware of the ways in which they have gained control over their practices.
\end{abstract}

Keywords: school work, teacher education, interdisciplinarity, curriculum reform, critical discourse analysis

Cite This Article: Alexandre Costa, and Izabel Magalhães, "Discourse Changes in Brazilian Teacher Education.” American Journal of Educational Research, vol. 3, no. 4 (2015): 467-475. doi: 10.12691/education-3-4-13.

\section{Introduction}

We can view the Brazilian educational system in terms of a few long stages by considering its epistemological basis. First, the Jesuit monks developed an efficient project for the colonization process, which went on for two centuries. After they had been expelled by the Portuguese Marquis of Pombal in 1759, there was a period of complete disorganization that lasted until the so-called Old Republic. Only in the 1930s, with the New State of Getúlio Vargas, this country had again a project of an educational system, now a nationalist and disciplinary one. Even with the military coup d'état of 1964, with their technical reforms, this model was maintained until it was discredited together with the military dictatorship. After the redemocratization movement of the 1980s, mainly with the 1988 Constitution and the Education Guidelines Law of 1996, we can see the beginning of a deep educational reform which was developed by successive governments, in three different stages: the national curriculum reform of the 1990s, the development of policies to induce the full-day in school model and the implementation of these policies.

Traditionally, school education has been offered in a part-time system, with schools offering classes for different groups in the morning, afternoon and evening.
The full-day in school model is an attempt to address critical social issues and to keep students in school all day as a way to keep them away from crime and violence, which are part of urban contexts in Brazil ([19]).

The social context of Brazilian cities like Goiânia, in the Midwest region, which is the locus of our research, is very complex, with the migration process from rural areas to the cities in the second half of the $20^{\text {th }}$ Century. Brazil has a tradition of social division among students, with the children of upper middle-class families attending private schools, while lower middle-class families send their children to state ("public") schools. Following recent legislation, mainstream state schools have faced challenging conditions with the need to account for students with a different background based on gender and race (what has been called the 'transversal approach'). With the requirement of legislation related to the inclusion of students with disabilities in mainstream schools, the situation has become very demanding on teachers ([3]).

However, the process of implementation of a full-day in school model was carried out in an inadequate way: it was imposed through top-down processes of continuing teacher education that were disconnected of the real conditions of schools, which resulted in demotivating teachers. In fact, it was a process of technologization of discourse. Discourse technologies are transcontextual techniques, which are discourse resources that can be used as strategies in a variety of contexts $([9,10,11])$, characterized 
mainly by what is known as a process of disembedding practices, that is removing a practice from one context and recontextualizing it in another context ([15]). These circumstances associated with salary devaluation of basic education teachers cut down the impact of this new curriculum; they also caused teachers to be confused and hopeless. But nowadays at a new stage of this reform, the central government's adoption of the full-day in school model has allowed for changes in school activities ([19]).

The debate about teacher identity reconstruction as part of a full-day in school model, which we discuss in this paper, is at the beginning of the third stage, a process dating back to the 1990s, and which is now in the course of being fully explored. We can notice the on-going replacement of part-time education in almost all regions, and we propose to describe and interpret the consequences of this change in schools, in their social practices and in the construction of a new teacher identity.

\section{The New Brazilian Education Order of Discourse}

We follow Fairclough's use of the term order of discourse: "An order of discourse is a network of social practices in its language aspect” ([11]). This notion was originally introduced by Foucault ([12]). The basis of the reconstruction of social practices and teacher identities is part of the discourse reordering of national education, mostly in the epistemological school matrix, as it is in the National Curriculum Parameters ([1,2]), PCN from now on. First, we will examine Kleiman and Moraes' proposal of the PCN operationalization ([18]), as it was developed in a process of continuing education and as part-time education. We will also discuss an apparent theoretical paradox in the relation between the notions of interdisciplinarity and transversality in the official guidelines, which was reproduced in the teacher education process. Then we will review the epistemological dimension of the transversal and interdisciplinary approaches ([7]). (For a full theoretical review see $[4,5,8,13,14])$.

\subsection{Interdisciplinarity in the Curriculum Reform}

Kleiman and Moraes' ([18]) view about the new organization of school work is directly related to the National Curriculum Parameters: they examine curriculum changes in practice, taking transversality to mean "a new way of looking into the same content”, proposing interdisciplinary collaborative projects related to intertextuality in reading ([18]). One aspect of this discussion is the notion of intertextuality, which we have adopted from Fairclough ([11]).

"In its most obvious sense, intertextuality is the presence of actual elements of other texts within a text - quotations. But there are various less obvious ways of incorporating elements of other texts. If we think, for instance, of reported speech, writing or thought, it is possible not only to quote what has been said or written elsewhere, it is possible, to summarize it.”

The notion of intertextuality underlies Kleiman and Moraes' approach, being seminal to discuss interdisciplinarity, as they present detailed examples of pedagogical projects based on reading different texts, like the news and weekly magazine stories, followed up by interdisciplinary activities.

In Kleiman and Moraes' approach, the lack of explicitness is not regular, and it may be due to confusion between "disciplinary relationship" and "teaching values" ([18]). In the PCN, interdisciplinarity is not different from disciplinary teaching by the aim of teaching values. In addition, as transversality can also be defined as an approach to school work that leads to the "inclusion of values” ([18]), this aspect would not be adequate to define the $P C N$ proposal in practice. Since the full-day in school model is based on the relationship between interdisciplinarity and transdisciplinarity in the school curriculum, it is necessary to discuss this relationship in our research.

In order to do this, it is useful to consider now van Leeuwen's comment on interdisciplinarity and transdisciplinarity. According to van Leeuwen ([20]), there are three models of interdisciplinarity: the centralist, the pluralist and the integrationist models. "A centralist model of interdisciplinarity is essentially a model of the relation between different autonomous disciplines” ([20]), while the pluralist model "seeks to bring such disciplines together, as equal partners, rather than that elements of other disciplines are incorporated in a 'centralist' discipline" ([20]). However, we need to bring an integrationist model into our debate about the PCN.

"Like the pluralist model, the integrationist model focuses on problems rather than methods and brings together researchers from different disciplines. But here it is recognized that no single discipline can satisfactorily address any given problem on its own. As a result, disciplines are seen as interdependent, and research projects involve team work with specific division of labour and specific integrative principles” ([20]).

As we can see, in addition to the contradiction between the epistemological and the pedagogical, both the PCN and Kleiman and Moraes' proposals have the problem of not adopting an integrationist view of interdisciplinarity, which corresponds to Fairclough's notion of transdisciplinary dialogue ([11]). It is this view that would be adequate to our debate on full-day school education.

The notion of interdisciplinarity has been developed by others that refer to different relations among disciplines, like multidisciplinarity, pluridisciplinarity and transdisciplinarity ([16]). Considering a discipline as "a systematic and organized set of knowledge with particular characteristics in relation to teaching, education, methods and subjects", disciplinarity would be "the scientific and specialized exploration in a given homogeneous domain of study". Thus, in the domain of scientific knowledge construction, a characterization of disciplinarity can be made according to the kind of relationship among disciplines ([16]).

1) Multidisciplinarity: a discipline set with different purposes and no collaboration among disciplines.

2) Pluridisciplinarity: the same as multidisciplinarity, but with some degree of relationship among disciplines, and with no hierarchical coordination.

3) Interdisciplinarity: connected disciplines by common principles and with some kind of purpose related to 
hierarchy, involving different degrees of methodological application.

4) Transdisciplinarity: here there is a deep connection among disciplines, promoting a structural discontinuity and the axiomatic resolution of their disciplinary origins, according with specific empirical purposes.

Given this classification, it is easy to acknowledge, on the one hand, the association of pluridisciplinarity to traditional schools and, on the other, the difficulty of taking transdisciplinarity to teaching practices in basic and secondary education. The multidisciplinarity approach is possible on all educational levels, when the different purposes correspond to different disciplines, applied separately. In pluridisciplinarity, as seen in education, the discipline objects can be partially connected, usually in the same area and within the aims of each discipline: between History and Geography, Mathematics and Science, etc.

In this sense, Kleiman and Moraes' references to reading practices, genre characteristics and the specific languages of the various disciplines have to do with common knowledge to all of them, which is no doubt interdisciplinary. As in the case of reading practices, all the transferences or abstract derivations should be made explicit and systematized according to the possibilities and scope of school work, its contexts, levels and varying modes, so that interdisciplinarity can take place.

As to transversality, according to the $P C N$ view, it involves work with "transversal themes", great sets of important and urgent social issues, which cannot be considered disciplines, but, on the contrary, cross over the content of existing disciplines. In this sense, for example, the teaching of values would not be the object of school courses such as "Morals and Civics", "Religion" or "Philosophy", as it happened in the past and is beginning to happen again in school practices. Issues like "respecting others and the self", or "sexual identity", for example, should be dealt with in teaching activities in all disciplines. Therefore, there are aspects that were not explicit in the $P C N$ or in investigators that commented on them.

Another aspect is the fact that transversality in the PCN is not related only to their disciplinary origins. If all disciplines can be associated with teaching values and if interdisciplinarity is an abstract relation in the content of disciplines, transversality can only be understood as facing concrete issues. Dealing with concrete and not with abstract issues like interdisciplinarity, transversality would also represent a general organization of school work, related to all disciplines.

Thus, a new epistemology of school work would discuss such issues as real problems for social actors, that is, they have to deal with time, space, identities and stances which are part of their social practices and their local communities. In this view, transversality would be the opposite of interdisciplinarity or its dialectical complementation; both can be taken to constitute the operational design of traditional disciplines.

Moreover, transversality can be seen as a link between social sciences and education, and both interdisciplinarity and transversality originate teaching content and social issues in school subjects, just as Bernstein's notion of "recontextualization” suggests ([6]) (see Figure 1). As we can see, implementing the PCN in schools would depend on a network of social practices and discourses ([9]). This network is based on the notions of intertextuality (see above) and interdiscursivity.

"In the most general terms, intertextuality is the combination in my discourse of my voice and the voice of another [...] Intertextuality can therefore be understood at two levels; on one level it is the presence in my discourse of the specific words of the other mixed with my words, as for instance in reported speech; on another level it is the combination in discourse of different genres - or, we might add, different discourses [...]. We use the term 'interdiscursivity' for the latter” ([9]).

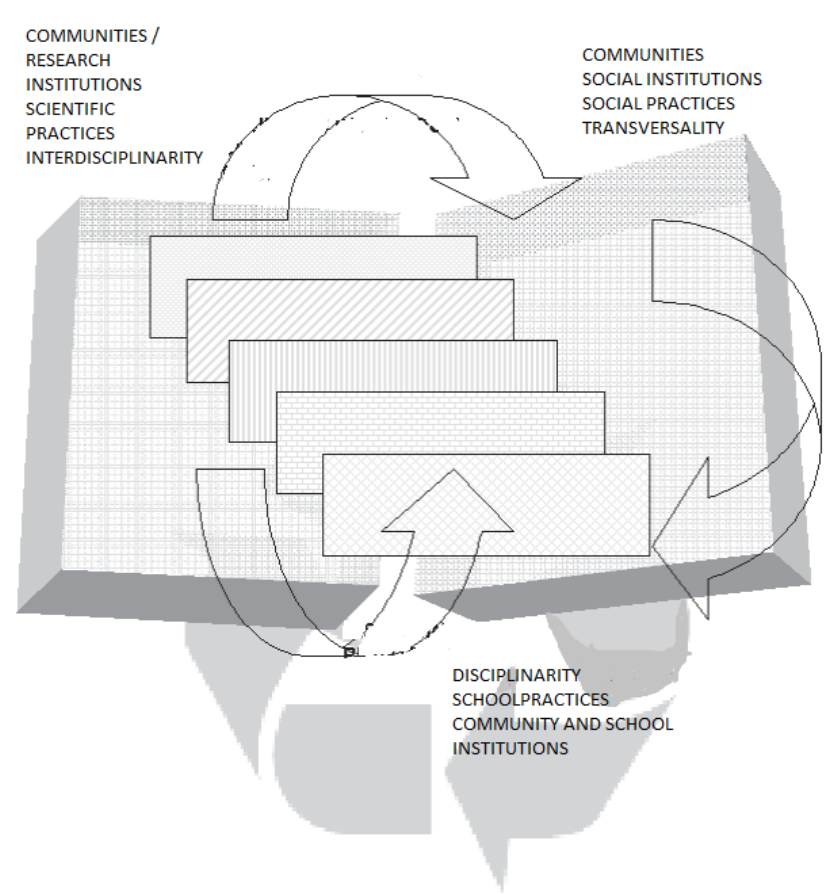

Figure 1. Epistemological relations in school work ([7])

This network of social practices and discourses has to be taken into consideration as we think of school work in a full-day in school model, considering a dialectical relationship between research institutions and scientific practices, and social institutions and practices in school. Teaching values ('transversality') needs to be based on this relationship.

We do not view an epistemological axis and a pedagogical one, as it is in the $P C N$ and in their commentators, such as Kleiman and Moraes ([18]). Both interdisciplinarity and transversality have epistemological origins and pedagogical effects. In this new school order of discourse, text production, distribution, consumption, and discourses ([10], [11]) have to do not only with valuing teachers' and students' collective work as a means of production of the required disciplinary relationships, but also with understanding in practice the discourse rationality of interdisciplinarity and transversality: the narrative slant of transversality and the abstract slant of interdisciplinarity.

In other words, teachers have a specific disciplinary education that ties them up to particular pedagogical purposes, which keeps them linked to a nucleus of content and competence more or less stabilized. In addition to the different disciplinary orientation of different teachers, students belonging to particular communities will also identify with particular transversal courses, and this will 
have different disciplinary and interdisciplinary consequences to school work.

But nowadays at a new stage of this educational reform, the central government's adoption of the full-day in school model has allowed for changes in school activities ([19]). The need to stay at school during the whole day not only developed teachers' awareness about their real working conditions, but also caused educational policies to adapt to local practices.

\section{Methodology}

We carried out observation of this process in ten schools of the state of Goiás, in the Midwest region of Brazil. These schools are observed by an educational institute of the third sector in teacher education, a NonGovernmental Organization [(17)], but this kind of observation cannot be generalized for the whole country. Our research can be characterized as ethnographic, with field notes of our class observation and long interviews with teachers, and it is also collaborative. In addition to this, we analyzed archive data. We also considered observation by a group of university students, who were doing course work at the schools and accepted collaborating with us.

At first, we registered our field notes based on observation in our regular visits to the schools. These notes were registered soon after our visits, and they were used in our attempts to understand what was going on. However, we relied mostly on what the participants said in the long interviews. All the interviews were transcribed in order to organize our corpus. The participants were teachers and staff.

Our motivation for this project was an invitation by the coordination of this institute to Alexandre Costa for a talk. At the beginning of 2013, we proposed our research to them, with a focus on teacher identity and practices.

All the schools, except one, are in the periphery of Goiânia, capital of the state of Goiás, which has a population of over one million and two hundred thousand, a city with all the problems of the Brazilian urban chaos. One of the problems we had was how to collaborate with ten schools located in areas of difficult access. This led us to discuss the uncertain conditions of teacher education.

The institute negotiates with the local government to improve the structural conditions of schools and awards their teachers a grant. Further, it deals with curriculum changes and conflicts between schools and the local government. It also mediated our research and collaboration agenda with the teachers and schools.

We decided not to make any specific references to the participants' roles that might identify them. This was one of the first things we agreed on. However, during the research process, it was sometimes difficult to have access to some people, documents and events. Moreover, we found a lot of internal disagreements. Therefore, we realized that our previous decision of replacing the participants' names was not enough.

As we have already noted, observation notes were taken during the research, including the collaborative activities (over two hundred pages). As the collaborative activities took place, and depending on the issues we were dealing with as part of our collaboration, we selected some participants to be interviewed. The interviews were rather informal at the beginning, but they became semistructured when we started to discuss about critical topics related to the full-day in school model. The total number of interviews was 30, but they varied both in length and quality. In addition to the field notes and interviews, we collected a lot of documents with a special interest in the textual chains of school practice. As we have already noted, a number of university students also took part in this research, writing reports as part of their teaching practice requirements. Thus, we have 50 reports as part of our data.

In the following sections, we will analyze examples from the interviews and reports. We will also discuss a pedagogical project, which was one of the documents we collected.

\section{Discussion}

\subsection{Identity and Teacher Practices}

We have selected to discuss here three interviews with the following participants: a member of the coordination of the Institute, 60, is a retired university professor; a supervisor, 40, is an experienced teacher and researcher; one of the teachers, 30, an Arts bachelor who is taking a further education course. The criterion for the selection of these participants was their experience in the full-day in school model. Our purpose here is to develop the notion of uncertainty, removing from the term its common sense meaning.

The director emphasizes the need to face uncertainty, developing two points: the belief that the frequent interaction among teachers constructs an identity of group belonging; the other is overcoming merely bureaucratic activities $([\ldots]=$ transcription interruption). The Portuguese transcript is followed by an English translation.

"O nosso projeto é uma tentativa de quebrar esse conceito [de turno e contraturno] e instituir um tempo escolar em que professores e alunos ficassem o tempo todo dentro da escola, porque na maioria, acho que $99 \%$ do Brasil, a escola de tempo integral é para o aluno e não para o professor."

[Our Project is an attempt to oppose this concept (of two periods: morning and afternoon) and establish a school time in which teachers and students stay in school all day, because in most cases, I think that $99 \%$ of Brazil, full-time school is for students and not for teachers.]

“Ao permanecerem na escola o tempo todo, o professor obrigatoriamente participa de dois tipos de planejamento. E quando eu falo de planejamento, não é o planejamento de curso e nem o planejamento burocrático feito para a Secretaria de Educação.”

[Staying in school all day, teachers necessarily take part in two types of planning. And when I talk about planning, it's not course planning, or the bureaucratic plan for the Education Office.]

Thus, the project director is aware that the basis of their intervention in teachers' agency is the reduction of fragmentation and disembedding of teaching activities by means of time reorganization of the local order of discourse. The establishment of a common time enables 
the use of different discourse technologies related to teacher education: study time, planning time, and administrative time.

This perspective can also be seen in the interpretation of the supervisor who was a facilitator, whose role was to observe teacher practice and report on it. In her interview, the construction of a process is detailed.

"Uma das qualidades do projeto é que os facilitadores não se comportavam de maneira intrusiva na escola. Eles estavam como observadores da prática e relatavam... e essa prática quando não era, talvez, correta, era discutida ao invés de ser imposta. [...] Era discutida pelas coordenadoras pedagógicas e pela direção da escola, com o Instituto” [com a participação direta da Diretora]. [...]

[One of the project advantages is that the facilitators were not intrusive in schools. They were observers of teacher practice and they reported on it [...] and when this practice wasn't right, it was discussed instead of being imposed on. [...] It was discussed by the pedagogical coordinators and the school director, with the Institute (with the director's participation).] [...]

"Sempre teve conflitos com isso. Assim... Mesmo... Mais por parte da Direção do que pelos próprios professores. [...] [Mas] Tem essa coisa do professor se sentir meio que castrado, né, meio vigiado, meio podado."

[There have always been conflicts with this. It comes more from the Direction than from teachers. [...] There's this problem of teachers feeling controlled.]

The fact that the facilitators reported on what they had observed is far from being empowering because their reports were interpreted as surveillance. However, the text distribution to the school pedagogical coordinators can also be interpreted as empowering the local pedagogical authorities in the schools, displacing the power struggle to the directors. Facilitators do not have an a priori authority, and concepts and positions are constructed on the basis of a shared time contract and activity organization.

The third example is from one of the teachers from one of the first schools in this project. Our interest here is related to the teacher's interpretation of identities, concepts and practices.

"Meu nome é John (this the name we used to refer to this participant), sou conhecido como Johnny [...] e gostaria, gostaria não, eu autorizo a publicação do meu nome na sua pesquisa [...] O senhor está fazendo uma pesquisa sobre a construção da identidade dentro da escola, e se eu renego a utilização do meu nome, eu estou automaticamente negando a minha identidade, enquanto profissional educador. Então, já que estamos falando sobre reconstrução de identidade por que não expor o que nós somos. E outra coisa, se a gente trabalha num processo criativo na área educacional, a gente tem que ter autonomia, autonomia de criação, e para a gente ter essa autonomia a gente tem de se expor. Tem de falar o que pensa, até porque quando a gente se expõe a gente vai contra um sistema que está invisibilizando personagens, protagonistas, educadores. E a gente não pode ser mais invisível do que nós já somos."

[My name is John (this is the name we used to refer to this participant) people call me Johnny [...] and I'd like, I authorize you to use my real name in your research.
[...] You're doing research about identity construction in schools, and if I'm against the use of my name, I'll be denying my identity as a professional educator. So if we're talking about identity reconstruction, why not show who we are. Another thing, if we're working in a creative process in the educational area, we have to have autonomy, creative autonomy, and in order to have autonomy, we have to show who we are. We have to show what we think because when we show ourselves we go against a system that's making people, protagonists and educators, invisible. And we can't be more invisible than we are.]

A drama teacher, John repeats some of the language of the project, such as "a creative process", and his speech is complex. However, he uses a number of lexical items related to teacher identity, conveying the way he feels in relation to the project and to the research. In another part of his interview, this teacher argues in favor of his own view, using such markers as "entenda quando eu falo" [do you understand what I'm saying], and he also classifies his activities as "multidisciplinary" and not "interdisciplinary".

What seems to be clear in our analysis is the process of technologization of discourse, in which teachers' identities are reconstructed systematically in training courses and in class observation reports and their pedagogical practices are recontextualized according to the government neoliberal orientation of performance data.

DISCOURSE TECHNOLOGIES
- Study time
- Adminning time
- They were observers of teacher practice and they
reported on it
- -..] and when this practice wasn't right, it was
discussed instead of being imposed on
It was discussed by the pedagogical coordinators and
the school director, with the Institute
- There have always been conflicts with this
- It comes more from the Direction than from teachers
- I authorize you to use my name in your research
- You're doing research about identity construction in
schools, and if I'm against the use of my name, I'1l be
denying my identity as a professional educator
- So if we're talking about identity reconstruction, why
not show who we are [...] if we're working in a
creative process in the educational area, we have to
have autonomy, creative autonomy, and in order to
have autonomy, we have to show who we are
We have to show what we think because when we
show ourselves we go against a system that's making
people, protagonists and educators, invisible [...] we
can'tbe more invisible than we are

Figure 2. Discourse technologies in the full-day in school project

In the interviews, we can note that the participants' traditional identities are reconstructed by a new discourse brought in by the institute and operating by means of a particular language that is highlighted in Figure 2. This language can be exemplified by "they were observers of teacher practice and they reported on it". We can also note that the teacher (John) suggests he has clearly been influenced by the institute language: "if we're working in 
a creative process in the educational area, we have to have autonomy, creative autonomy". Two points are worthy of mention here: 1) the teacher talks about conflicts with the direction, "There have always been conflicts with this", on account of the fact that teachers feel controlled, "There's this problem of teachers feeling controlled". This brings us to the second point: teachers' control is probably part of an attempt by the institute to shape teachers' identities according to the neoliberal logic of producing docile autonomous teachers, who are ready to produce performance data to fill in their statistics in order to show production results in education.

The reorganization into planning, study and administrative time can be seen in terms of identity shaping as discourse technologies, manifesting in what the participants say in the interviews. They refer, for example, to conflicts, feeling controlled by the institute direction, identity reconstruction, being invisible.

\subsection{University Students' Perception}

In the first year of research, we sent 50 university students to the schools as part of their teaching education. At the end of term, they had to write an observation report. In this section, we will present three examples from their reports.

The first example is from the report of a 24-year-old female student, Carla, doing a research project in educational strategies. In the report, Carla mentions the local teacher's difficulty to manage the class.

"[...] the first point that called my attention in my observation was the relation among organization, didactics and content presented by the teacher. After 45 minutes, we moved to another room in which two groups of different grades were together. There were thirty students there, and they were very excited about watching a play. The teacher tried to organize the three groups, so that they could continue to work on the reading activity that had been in progress before they moved, but in the end all she could do was organize the students who were very excited. Some of the students went to watch the play and others were sent home.”

In this example, the student questions the institute effort to keep on planned activities as a necessary value. She notes that this problem was recurrent because of the lack of staff, and she adds that although teachers were oriented in a given way, they had no resources to follow their planning, and that they were always "in their limit". Thus, teachers were empowered, but at a high cost.

The second example comes from another female student, Ana, 23 years old. In her report, she gives a lot of attention to the 'transversal activities', giving the following reasons:

"First, it is amazing that these students have the opportunity to take part in these workshops of sports, art, literature and other activities. And I think that these activities are more organized than traditional ones.”

She reports on the karate workshop:

"Today I observed the karate workshop. There were 20 students of different age groups, including one with a special condition (she does not describe the medical problem). Some of them were wearing a kimono, but others were not. But all of them took part in the workshop. The teacher was very serious; he did not talk much, but just led the students to do the movements of this martial art. The students just followed the teacher's instructions quietly but they looked motivated.”

This kind of activity is entirely outside traditional parttime education. It had a great impact as it was introduced in the local school order of discourse. The characteristic discipline of martial arts is a kind of hyperbole in the context of indiscipline in regular school classes. It is clear from what we heard that university students see it as a 'solution'.

The last example comes from a male student, Ricardo, 25 years old, a religious person and a Spanish teacher in our Language Center. He describes what we view as a borderline discipline problem.

"The teacher shouts telling the students to be quiet. She calls the names of several students who were chatting and threatens not to mark their work. However, her threatening shouts have no effect. On the contrary, some students start to shout too, and one of them yells 'Get out of the way, you damned!' The teacher is very irritated, and she walks to the back of the room and tells the student who had yelled to behave himself, and to be polite to his colleagues. A few minutes later, this same student starts yelling again, saying, 'Excuse me, excuse me!'”

Here there was a negotiation between ordinary behavior and the teaching of values. Of course, it is easy to praise the karate teacher, but it is up to us to acknowledge different moments in school practices, in which the new model of time organization in schools and the presence of new social actors have effects on teachers' and students' identities and in their perception of regulations.

\subsection{A Pedagogical Project Textual Chain}

In this final section of analysis, we will discuss a textual chain of a 'Pedagogical Project'. We are concerned with the structural documentation that leads the planning of events and practices described above. There is no doubt that this first systematization is a kind of 'dispersion system', using Foucault's words [(12)]. But we believe that the consideration of this global planning shows some progress or transgression of the part-time model towards the full-day in school education.

First, let us consider the general structure that will be constitutive of practices and events in the school year. As a result of the time planning that precedes working with students, the summary of this document presents the new relations in the new model. It needs to present traditional schooling but needs to make reference to the national program of induction of the full-day in school model. The important aspect to notice here is the permanence of the division between part-time education and the full-day in school model.

The new approach is represented mainly by Section '7' about specific transversal projects.

By examining the Project Summary, but also our field notes, we understand that it is a constitutive document of resulting practices, events and texts during the school year. This document is not only a general planning device; it can also be seen as a State Education Office control document. Presently, this genre in Goiás schools is previously defined by the government and must be followed by schools, and it is systematically surveilled by staff known as 'Pedagogical Support'. 
Summary

Identification

History

1. Presentation

2. Justification

3. Methodology

4. Objectives

4.1 General

4.2 Specific

5. Curriculum

6. Educational Structure

6.1 Basic Curriculum and Activities

6.2 Selected Workshops

6.3 Specialized Educational Care (AEE)

6.4 Oriented Break

6.5 Planning

7.Projects

7.1 I Recycle Cooking Oil

7.2 Movie in the Classroom

7.3 Reading and Writing: Reading Makes a Difference

7.4 A Mathematics Game

7.5 Aquatic Science

7.6 Brazilian Indigenous People and the Marajoara Art

7.7 Geometrical Solids

7.8 Data Registration

7.9 The Solar System, Earth and the Four Seasons

7.10 Discovering Shapes and Learning Mathematics with the Egyptians

7.11 Different Mathematics Games

7.12 Becoming Aware of Reading and Text Production

7.13 Brazil in the World Cup

7.14 Fun Numeracy

7.15 Carnival: the "Torcida do Fuleco" Group

7.16 Valentine's Day

7.17 Playing with One's Body

7.18 Capoeira in School

7.19 School Circus

7.20 Illustrated Picnic

7.21 Values in Story Telling

7.22 Corozum

8. Physical Structure

9. Organizational Structure

9.1 School Direction

9.2 General Coordination

9.3 Pedagogical Coordination

9.4 Discipline Coordination

9.5 Office

9.6 Staff

9.7 Snack Manager

10. School Council

11. Resources

11.1 Didactic

11.2 Financial

12. Programs

12.1 Program 'More Education'

12.2 Program 'Health in School'

12.3 Program 'Misbehavior Control and Dialog Strengthening in School'

13. Partnership

13.1 Institute

13.2 Learning Laboratory

14. Learning Intensification Period

15. Partial Progress

16. Evaluation

16.1 Learning Evaluation

16.2 Institutional Evaluation

16.3 Peadagogical Project Evaluation

17. Professional Framework

Attachments
We noted that this staff's role was to read the schools general planning and the teachers' specific planning. In fact, it was a kind of bureaucratic reading that was carried out quickly and superficially. In our research context, the Pedagogical Support staff did not examine the activities of the schools partnership with the institute.

In other words, it is important to say that there was a very clear conflict between the two control instances. Consequently, the teachers were in the center of this conflict, positioning themselves either in collaboration with or in resistance to one of the two sides. Once again, we must emphasize that this professional paradox in which the teachers see themselves reinforces what we said previously about the process of disembedding of practices. Even if the set of schools and the institute support constitute a local order of discourse, this order is not integrated as a partnership with the government. We can see the complexity of these wide scenarios, which have gradual and founding effects on practices, social actors and their identities.

For example, when the Pedagogical Project deals with the activities time, the views of part-time schools and fullday in school education are quite differentiated, as the following quotation indicates.

"From 7 o'clock to 11:25 a.m., the obligatory subjects of the curriculum take place. In the next period, from 1 to 3 p.m., complimentary activities take place, grouping students in the following activities: Oriented Studies, Literacy Support, Practical Mathematics, Scientific Initiation, and Daily Experiences."

Only after focusing on the part-time school subjects, the Project defines the specific time of the activities inducing the full-day in school model. In the next example, we can also see the time definition of the division of activities, even if the purpose of this is a presentation of the activities of the new approach.

"From 3 to 4:45 p.m., students are oriented to develop activities in visual arts, acrobatics, capoeira [afroBrazilian fight], circus practice, story-telling, choir, dance, flute, futsal, games, karate, drums, drama, table-tennis and guitar."

In addition to the different timing of the two models, the social actors are not the same. On the one hand, the study and planning time is fixed; on the other, different roles are performed by teachers in the two models.

"Every teacher has 8 hours and 30 minutes weekly, in the total number of hours, to plan activities, individually or collectively. This activity is led by the Pedagogical Coordination."

One also has to deal with the inclusion requirements for students with disabilities, following national legislation with the support of the international community, as we can see in the following quotation.

"The school has 16 support teachers for special needs students, contributing for their inclusion in school and in society. The World Conference on Special Educational Needs, known as the Salamanca Declaration, points out that the States should guarantee that the education of people with disabilities should be an integral part of the educational system (UNESCO, 1994)".

At last, after attending to this structural division of views, the text conveys the methodology and topics dealing with what we have called transversal activities. The term used is always interdisciplinarity, which indicates a 
lexicalization process that reduces the complexity of the new epistemological matrices discussed previously. On the one hand, this lexical choice can mean a simplified perception of the collective work among different subjects. On the other, it shows that the Pedagogical Project is not based on official documents. The following quotation suggests that the notion of transversality and its intertextual relation with the narrative of the text are deleted.

"The specific methodology should aim at interdisciplinarity by designing collective projects that stimulate students to do more work on the fields included in the curriculum, as well as learn more about art and culture. The aim is that what we teach by means of educational projects can develop education for life, education focused on citizenship, education for critical subjects. 'Intelligence related to the world, learned as it is produced and the communicability of what is learned are tasks attributed to the subject, and in this process he/she must become critical' (FREIRE)."

We can note that the reference to Freire ([22]) takes us to the period before the reorganization of the 1990's, and even if it is accepted by the institute, it has to do with teachers' initial education. Next, we will present all the workshops that are part of the Pedagogical Project and which are developed in small projects which are supposedly interconnected.

As we said before, there was a crisis in the relation between research and collaboration. We were given a copy of the Pedagogical Project, but the same did not happen with the workshops projects. Access to these projects was very difficult for one obvious reason: even if it is referred to as interdisciplinary, it is here that one can note the verticality of the transversal approach. Thus, in fact, it is not interdisciplinary at all.

However, the duplication of the control instances did not stop collective work, even if it demanded more work from individual teachers. As it has already become clear, this is the reason for the increased teacher stress, and as a third interactional part, our research in spite of being collaborative was associated with one or both of the control segments.

We will now present the definitions of the activities that we are calling transversal. In their brief descriptions, we can note interdiscursive lexicalizations: although they are characterized as workshops, a great number of their descriptive terms are derived from traditional school activities related to part-time education (for example, "Geometrical Solids: it carries out the study of geometrical shapes and solids based on the students' daily life").

"I Recycle Cooking Oil: it retrieves the concept of common good and multiplies environmental ideas and actions for the students' whole education."

"Movie in the Classroom: it places the movie art in the teaching-learning process by the audiovisual means and multidisciplinary teaching, driving students to narrative."

"Reading Makes a Difference: it stimulates students to a contemporary and modern reading process."

"A Mathematics Game: using a didactic resource, it exercises the basic operations stimulating learning in an amusing way."
"Aquatic Sciences: one can make students develop their knowledge, awakening their curiosity and awareness towards scientific knowledge by means of aquatic sciences and mathematics."

"Brazilian Indigenous People and the Marajoara Art: it develops the students' knowledge of the Marajoara people's culture.”

"Geometrical Solids: it carries out the study of geometrical shapes and solids based on the students" daily life."

"Data Registration: reading about statistics, summary, data registration, understanding and constructing figures and tables."

"The Solar System, Earth and the Four Seasons: learning about how earth and the solar system were formed, their movements, size and characteristics.”

"Discovering Shapes and Learning Mathematics with the Egyptians: it stresses the role played by the Egyptians in mathematics studies, exploring history and the Egyptian vocabulary in the English language.”

"Different Mathematics Games: it offers students the opportunity to develop their knowledge in amusing interactive activities and experiences.”

"Becoming Aware of Reading and Text Production: it develops the reading practice in education, offering moments of cultural information in an amusing way in the production of a short story book."

"Brazil in the World Cup: it makes a comparative analysis of Brazil in the 1950s, commenting on its development to the present. It also points out the countries that took part in the World Cup and their flags."

"Fun Numeracy: it makes students learn the basic operations, developing their cognitive abilities, and making this kind of learning well known in the school context and in other contexts."

"Carnival: the 'Torcida do Fuleco' Group: it examines the origin of Carnival, focusing on Brazilian culture, its manifestations and the influence of the African, Indigenous and European peoples in this feast."

"Valentine's Day: it awakens the students' interest in the English language, considering the history of this celebration and developing respect for other cultures." "Playing with one's Body: it aims at remembering games and folk play, developing, in a dynamic and oriented, way the students' physical condition."

"Capoeira in School: it stimulates the students' artistic, historical and cultural development, considering studies about changes in Capoeira from the beginning of Regional Capoeira to the present."

"School Circus: bodily practices of gymnastics oriented to circus language (rhythm, art, acrobatics,...); it aims at developing collective bodily expression based on principles of gymnastics.”

"Illustrated Picnic: it provides an amusing and celebrating moment among the students involved, presenting the world of illustrators from Goiás with nine local illustrators."

"Values in Story Telling: it develops critical reflexive reasoning in students, based on human values in storytelling."

"Corozum: it consolidates the organization of the dramatic piece Corozum, with interdisciplinary relations among music, dance, visual arts and literature, 
making it possible for students to have an amusing experience of music, gestures and poetry characteristic of the children's world.”

Again, it is important to point out that the great number of documents about the National Curriculum Paradigms $(P C N)$ and their discussion in continued education have not been presented here in depth. This suggests that these activities have in fact emerged from interdisciplinarity and transversality, due to the institute work, to the collective work of teachers and the influence of their initial education. It would not be wrong to say that teachers reinvent their matrices, and this can be considered empowering, for it escapes the mere bureaucratic reproduction of official topics, which we are treating here as discourse technologies. On the other hand, when we consider the demands of the two control segments (local government and the institute), this whole process, first of organization and second of workshop practice, enhances to a great extent teachers' work, pressed as it is permanently and in different ways.

\section{Conclusion}

What we are calling uncertainty is related to the simplification of school activities in the project, meaning that the curriculum reform has not reached schools. Thus, access to them is in an autonomous space-time center in each school. As the schools are linked to the educational system, teachers experience two different realities: one of bureaucratic obligations to the local government and the other related to new ways of working on the basis of general and flexible principles.

In his interview, John refers to transdisciplinarity, which seems to correspond to integrationist interdisciplinarity ([20]), when he views himself as part of a group that is oriented to social engagement problems, in interdependent and equally valued disciplines. This certainly suggests a big change in progress, indicating the replacement of teacher identity denial, for example, in John's feeling of being invisible, in new accounts, in different space-time contexts. These new accounts point to strict control over teachers as production units in a neoliberal order.

On the other hand, both the perception of teachers in their process of education and the analysis of the genre Pedagogical Project allow us to understand the enormous complexity of the conflict between change in the schools pedagogical practices and its emergence in a context of double control by the surveillance of two power segments. The university students' reports offer clues to understand how social actors who are outside the local school order of discourse immediately activate general commonsense views. These are internalized views from their own school experience, but some of them have already advanced in their theoretical awareness acquired at the university.

It is useful to repeat that the excessive control over teachers produces teacher resistance as they are strengthened by their daily struggle in facing these circumstances. In short, considering all these aspects, we can say that we are in a process of questioning in all senses, even of control. This is a moment of serious conflict, a real crisis, but hopefully it can give rise to new opportunities.

\section{Acknowledgement}

This paper is based on the research project "Policies of the Implementation of Full-Day Education in the State of Goiás and Teacher Education: a Discourse Analysis of the Reconstruction of Practices, Knowledge and Teacher Identities”, funded by the Research Funding Foundation of the State of Goiás (FAPEG - PD/Brazil n. 201210267000829), in 2013-2014. We thank this institution for funding our research.

\section{References}

[1] Brasil. Ministério da Educação e do Desporto. Secretaria de Educação Fundamental. Parâmetros Curriculares Nacionais: terceiro e quarto ciclos do ensino fundamental: língua portuguesa. Brasília, 1998.

[2] Brasil. Ministério da Educação e do Desporto. Secretaria de Educação Fundamental. Parâmetros Curriculares Nacionais: terceiro e quarto ciclos do ensino fundamental: temas transversais. Brasília, 1998.

[3] Magalhães, I. Letramentos e identidades no Ensino Especial. In: Magalhães, I. (ed.) Discursos e práticas de letramento. Campinas, SP: Mercado de Letras, 2012. p. 159-194.

[4] Bakhtin, M. Para uma filosofia do ato responsável. Pedro \& João Editores, 2010.

[5] Bakhtin, M. Marxismo e filosofia da linguagem. São Paulo: Hucitec, 1986.

[6] Bernstein, B. Pedagogy, symbolic control \& identity theory. London: Taylor and Francis, 1996.

[7] Costa, A. "Interdisciplinaridade e transversalidade": considerações sobre a epistemologia do trabalho escolar brasileiro. Cadernos de Linguagem e Sociedade, 9 (2), 2008. p. 40.

[8] Costa, A. "Ensaio sobre a desrazão dialógica”: apontamentos sobre uma ontologia da compreensão. Via Litterae, v. 4, p. 183190, 2012.

[9] Chouliaraki, L.; Fairclough, N. Discourse in late modernity: rethinking critical discourse analysis. Edinburgh, England: Edinburgh University Press, 1999. p. 49.

[10] Fairclough, N. Discourse and social change. Cambridge: Polity Press, 1992.

[11] Fairclough, N. Analysing discourse: textual analysis for social research.London: Routledge, 2003. p.24, 39, 220.

[12] Foucault, M. A arqueologia do saber. 6. ed. Rio de Janeiro: Forense Universitária, 2002.

[13] Geraldi, J. W. A aula como acontecimento. São Carlos: Pedro \& João Editores, 2010.

[14] Geraldi, J. W. Portos de passagem. São Paulo: Martins Fontes, 1991.

[15] Giddens, A. As consequências da modernidade. São Paulo: Editora UNESP, 1991.

[16] Iribarry, I. N. Aproximações sobre a transdisciplinaridade. Algumas linhas históricas, fundamentos e princípios aplicados ao trabalho de equipe.V Psicologia: Reflexão e Crítica, 16 (3), 2003. p. $3 ; 4 \mathrm{ff}$.

[17] Instituto Jayme Câmara. Projeto Ser Pleno: projeto experimental de educação integral em tempo integral. IJC: Goiânia, 2014.

[18] Kleiman, A. B.; Moraes, S. E. Leitura e Interdisciplinaridade: Tecendo Redes nos Projetos. Campinas, SP: Mercado de Letras, 1999. $10 \mathrm{ff}$; 27; 23.

[19] Moll, J. (ed.). Caminhos da educação integral no Brasil: direito a outros tempos e espaços educativos. Porto Alegre: Penso, 2012.

[20] van Leeuwen, T. Three models of interdisciplinarity. In: Wodak, R. \&, Chilton, P. A new agenda in (critical) discourse analisys: theory, metodology and interdisciplinarity. Amsterdam: John Benjamin Publishing Company, 2005. p. 3; 6; 7-8.

[21] Van Maanen, J. Tales of the field: on writing ethnography. Chicago University Press, 1988.

[22] Freire, P. Pedagogia do oprimido. 26 ed. Rio de Janeiro: Paz e Terra, 1999. 